\title{
The IgH 3' regulatory region and C-myc-induced B-cell lymphomagenesis
}

\author{
Nour Ghazzaui ${ }^{1, *}$, Alexis Saintamand ${ }^{1, *}{ }^{,}$Hussein Issaoui $^{1}$, Christelle Vincent- \\ Fabert $^{1}$ and Yves Denizot ${ }^{1}$ \\ ${ }^{1}$ Université de Limoges, Centre National de la Recherche Scientifique, CNRS UMR, France \\ * These authors have have contributed equally to this work \\ Correspondence to: Yves Denizot, email: yves.denizot@unilim.fr \\ Keywords: c-myc, 3' regulatory region, lymphomagenesis, transgenic mice, HDAC \\ Received: August 15, $2016 \quad$ Accepted: October 05, $2016 \quad$ Published: October 08, 2016
}

ABSTRACT

Deregulation and mutations of C-myc have been reported in multiple mature B-cell malignancies such as Burkitt Iymphoma, myeloma and plasma cell Iymphoma. After translocation into the immunoglobulin heavy chain (IgH) locus, c-myc is constitutively expressed under the control of active IgH cis-regulatory enhancers. Those located in the IgH 3' regulatory region ( $3^{\prime} R R$ ) are master control elements of transcription. Over the past decade numerous convincing demonstrations of 3'RR's contribution to mature c-myc-induced lymphomagenesis have been made using transgenic models with various types of IgH-c-myc translocations and transgenes. This review highlights how IgH 3'RR physiological functions play a critical role in c-myc deregulation during Iymphomagenesis.

\section{INTRODUCTION}

The immunoglobulin heavy chain (IgH) locus undergoes numerous changes during B-cell differentiation, affecting transcription, $\mathrm{V}(\mathrm{D}) \mathrm{J}$ accessibility to recombination, class switch recombination (CSR) and somatic hypermutation (SHM) [1, 2]. Ongoing recombination and mutation throughout B-cell development, via Rag1/Rag2 and AID targeting [1, 2], make the $\mathrm{IgH}$ locus a hotspot for translocations. Several human mature B-cell lymphomas are marked by oncogene translocations into the IgH locus [3]. Bcl-2 and cyclin D1 translocations found respectively in follicular lymphomas (FL) and mantle cell lymphomas (MCL), occur during $\mathrm{V}(\mathrm{D}) \mathrm{J}$ recombination. c-myc translocation, the typical hallmark of Burkitt lymphoma (BL), is linked to either CSR or SHM. Cyclin D1/D3, c-myc or c-maf translocations found in myeloma are clearly related to CSR [4]. Transcription of the IgH locus is under control of cis-regulatory elements $[1,2]$. These transcriptional enhancers obviously intervene in oncogene deregulation during B-cell lymphomagenesis. During the past decade the roles and mechanism of actions of various IgH cisregulatory enhancers have been clarified. At the same time various transgenic mice models have been developed in order to mimic human mature B-cell lymphomagenesis. A number of them use c-myc as a deregulated oncogene and the $\mathrm{IgH} 3^{\prime}$ regulatory region ( $\left.3^{\prime} \mathrm{RR}\right)$ as an oncogene deregulator. Indeed, c-myc is well known to be both an important regulator of cell growth and apoptosis through its action on cell cycle progression, cell metabolism, cell differentiation, cell death receptor signaling and DNA damage recovery [3]. This review describes how IgH 3'RR physiological functions might play a critical role in c-myc oncogene deregulation during mature B-cell lymphomas and why 3 'RR targeting would be an interesting promising strategy in human lymphomagenesis.

\section{IGH CIS-REGULATORY ELEMENTS}

IgH cis-regulatory elements are major locus regulators (Figure 1). Two important regions have been identified. The intronic 5' E $\mu$ enhancer is mandatory for VDJ recombination and thus plays a key role during early steps of B-cell development [2, 5]. VDJ recombination is initiated by Rag1/Rag2 nucleases. The resulting Raginduced DNA double-strand breaks are ideal sites for oncogene translocation. The IgH 3'RR promotes SHM $[6,7]$, CSR [8-10], $\mu$ transcription [11] but not VDJ recombination [12]. In germinal centers, SHM and CSR are AID-mediated modifications. SHM mainly occurs in VDJ exons for high affinity antibody generation. CSR is required for synthesis of non IgM Ig. Although these events imply different mechanisms, they both require the 
initiation of simple- or double-strand breaks by AID, which dramatically increase the risk of oncogene translocation. The 3'RR, as the principal AID-dependent recombination regulator, is the major player during late $\mathrm{B}$-cell maturation stages. The mouse 3'RR is downstream from the IgH Cac gene and shares a strong structural homology with 3'RR located downstream from each human $\mathrm{IgH} \mathrm{C} \alpha$ gene $(\mathrm{C} \alpha 1$ and Ca2) [13] (Figure 2). 3'RR structural homology has been conserved during vertebrate evolution highlighting its importance during B-cell lymphopoiesis. The mouse 3'RR contains four transcriptional enhancers (hs3a, hs 1,2, hs3b and hs4). hs1,2 is flanked by inverted repeat sequences and is the center of a $25-\mathrm{kb}$ palindrome bound by two inverted copies of hs 3 enhancers (hs $3 a$ and hs $3 b$ ) [14]. hs4 is downstream from the palindrome. Each 3'RR enhancer has weak in vitro activity, but a synergistic and potent global effect in transgenes, especially when the palindromic 3'RR architecture is maintained [15]. Recently, sequential activation and distinct functions were reported for distal (hs4) and proximal (hs3a-hs1,2- hs3b) modules within the 3'RR [16]. Transgenic mice have shown that the 3'RR palindrome is of key importance for efficient SHM [17]. Together, the four enhancer elements are sufficient for efficient germline transcription, CSR and Ig transcription [7]. These transcriptional enhancers might thus play a role during the oncogene deregulation found in several types of mature B-cell lymphomas.

\section{Transgenic and knock-in models of c-myc lymphomagenesis}

The cis-regulatory E $\mu$ element was first suspected to be the c-myc deregulator in BL. However, E $\mu$-c-myc transgenic mice developed immature B-cell lymphomas [18] clearly different from a human BL which has a mature B-cell signature [19]. In human BL, c-myc translocation breakpoints are found in the VDJ (i.e., endemic BL with $\mathrm{E} \mu$ and 3'RR at the IgH locus) or in the switch $\mu$ region (i.e., sporadic BL with $\mathrm{E} \mu$ deletion and 3'RR at the $\mathrm{IgH}$ locus). Thus, a 3'RR was progressively suspected to be a good candidate for oncogene deregulation. Mouse and human 3'RRs share a strong structural homology [13]. Mouse models exploring the $3^{\prime} \mathrm{RR}$ role in B-cell malignancies should provide interesting data concerning human B-cell lymphoma development.

The first model investigating the role of $\operatorname{IgH} 3$ ' $\mathrm{RR}$ in c-myc deregulation was in knock-in mouse in which 3 ' $R R$ was inserted 5' to the endogenous c-myc locus (3'RR-mycknock-in mice) [20]. After ten months, mice developed clonal BL-like B-cell lymphomas with a B220 $\operatorname{IgM}^{+} \operatorname{IgD}^{\text {low } /}$

\section{Mouse IgH locus}

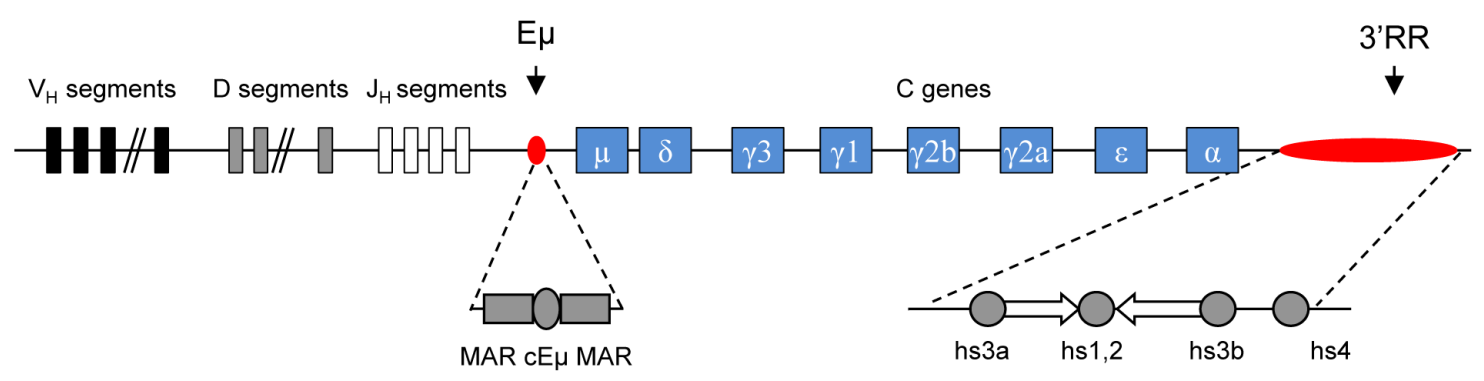

\section{Human IgH locus}

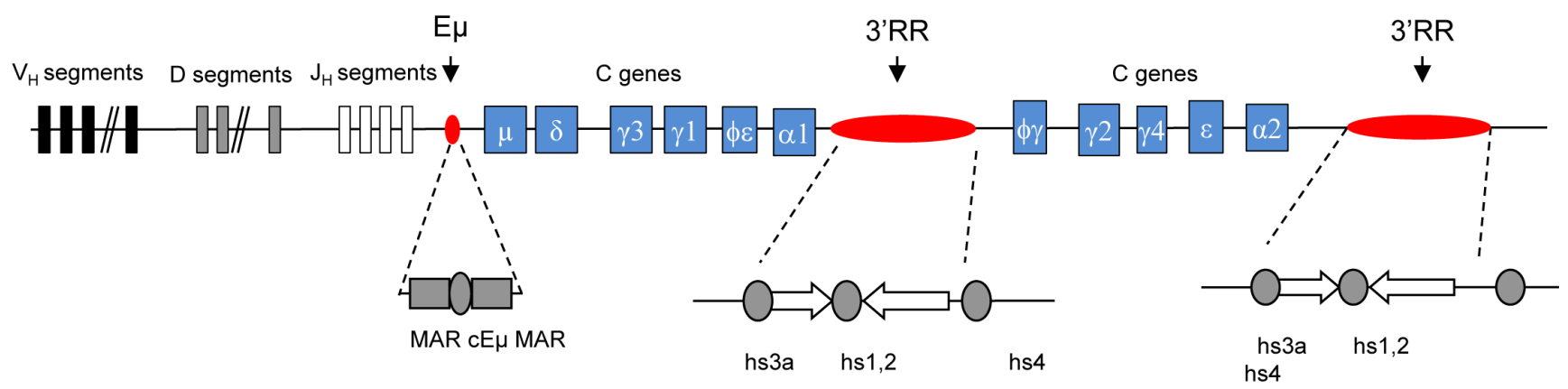

Figure 1: Murine and human IgH locus. Upper panel: Schematic diagrams of the murine IgH locus. Locations of E $\mu$ (with its flanking matrix attachment regions, MARs) and 3'RR (encompassing four transcriptional enhancers with flanking inverted repeats) are highlighted. Lower panel: Schematic diagrams of the human IgH locus. Locations of E $\mu$ MARs and the two 3'RR (encompassing three transcriptional enhancers with flanking inverted repeats) are highlighted. 
${ }^{\text {neg }}$ phenotype. In these mice, 3'RR stimulated endogenous c-myc transcription triggering both cell proliferation and apoptosis in pre-malignant spleen B-cells. Lymphoma development required multiple "hits" in addition to c-myc deregulation. Mutations in the p53-ARF-Mdm2 apoptotic pathways occurred during lymphoma development. Thus, only recently, has 3 'RR been shown to be sufficient for c-myc deregulation leading to BL-like lymphomas.

Results with 3'RR-myc-knock-in mice were confirmed using mice having a c-myc-3'RR transgene [21]. Pre-malignant spleen B-cells from c-myc-3'RR mice proliferated more rapidly in response to mitogen signals and showed a higher apoptosis rate. At twelve weeks, c-myc-3'RR mice developed BL-like lymphomas or diffuse anaplastic plasmacytomas. BL-like lymphomas were $\mathrm{B} 220^{+} \operatorname{IgM}^{+} \operatorname{IgD}^{+}$with a "starry sky" appearance. Transcriptome analysis indicated alterations in the growth program and Ras-p21 pathway. Compared to 3'RR- myc-knock-in mice, the c-myc-3'RR mice developed two different phenotypes of B-cell lymphomas with two different kinetics of appearance and lacked mutations for the p53-ARF-Mdm2 apoptotic pathways [21]. In the 3'RR-myc-knock-in model, these differences imply 3'RR targeting the endogenous c-myc locus directly. The 3 'RR would affect c-myc locus by destroying with its insertion some positive/negative endogenous cis-regulatory elements or by influencing their activation through the 3'RR long range transcriptional activity.

Interestingly, the occurrence of lymphoproliferations in c-myc-3'RR mice was sensitive to genetic background. C57Bl/6 mice developed BL-like lymphomas, while none occurred in a Balb/c background [22] known to have an allelic variant in the coding region of the $\mathrm{p} 16^{\mathrm{INK} 4 \mathrm{a}}$ tumor suppressor gene that produces a protein with impaired activity. The regulation of cell cycle progression is managed by cyclins and cyclin dependent kinases

\section{KI models}

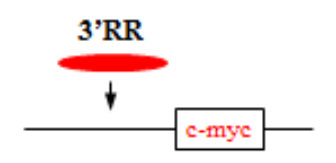

$\mathrm{KI}$ of the 3'RR 5' to theendogenous c-myc [20]
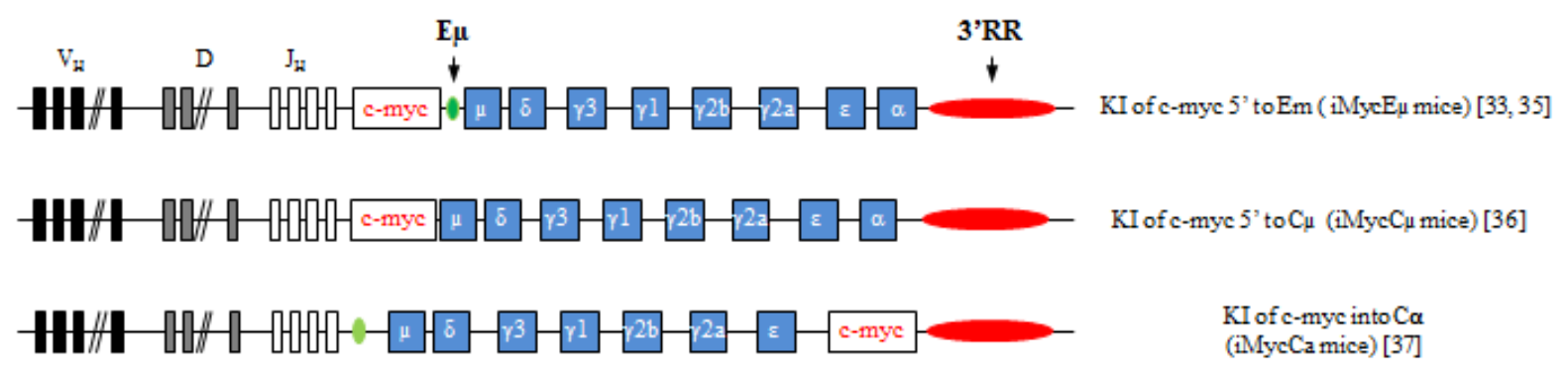

\section{Transgenic models}

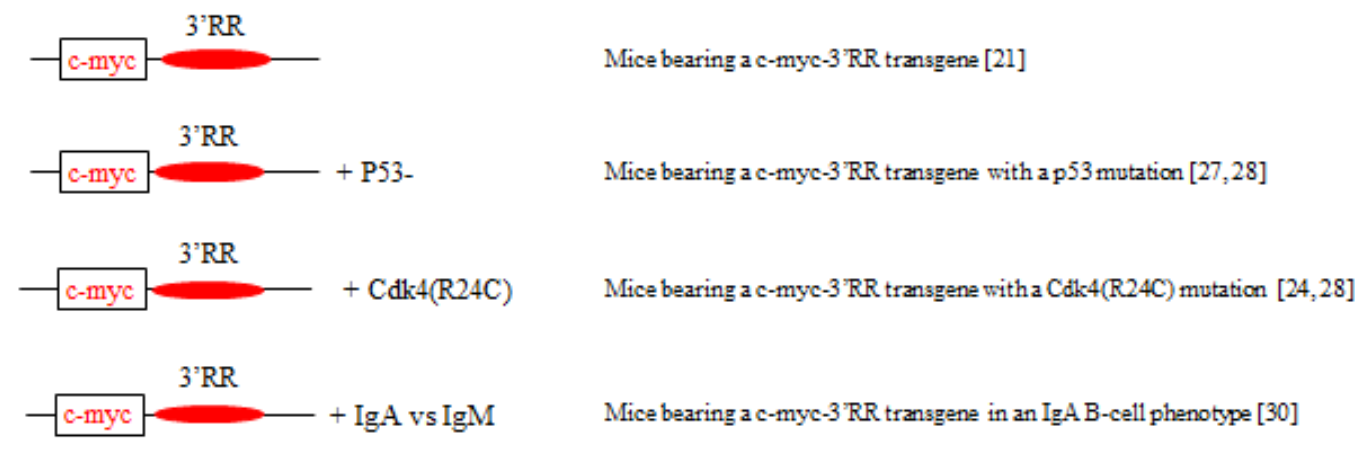

Figure 2: Knock-in and transgenic models of 3'RR induced c-myc lymphomogenesis. A schematic representation of the various knock-in (upper panel) and transgenic models (lower panel) reporting that the 3'RR deregulates c-myc leading to B-cell lymphomogenesis. Bibliographic references are in brackets. 
(Cdk). Cdk4 and Cdk6 are chief catalytic subunits of the cyclin $D$ family of proteins that govern $\mathrm{G}_{1} / \mathrm{S}$ phase progression. The tumor suppressor protein $\mathrm{p} 16^{\mathrm{INK} 4 \mathrm{a}}$ and all members of the INK4 family bind specifically to Cdk4 or Cdk6 and inhibit the cyclin D-Cdk4 and cyclin D-Cdk6 complexes formation. Breeding $\mathrm{Cdk} 4^{\mathrm{R} 24 \mathrm{C}}$ mice (a knock-in strain expressing a Cdk4 resistant to $\mathrm{p} 16^{\mathrm{INK} 4 \mathrm{a}}$ inhibition and other Ink4 family members [23]) with c-myc-3'RR mice (that developed aggressive BL) led to the development of clonal indolent blastoid MCLlike lymphoma $\left(\mathrm{CD} 19^{+} \mathrm{IgM}^{+} \mathrm{CD}^{+} \mathrm{CD} 43^{+} \mathrm{CD} 23^{-}\right.$cells) in c-myc-3'RR/Cdk4 ${ }^{\mathrm{R} 24 \mathrm{C}}$ mice [24]. Large amounts of Cdk4/ cyclin D1 complexes were the main hallmark of these lymphomas. Although silent in non-malignant B-cells, a defect in the Ink4-Cdk4 checkpoint could contribute to lymphomagenesis in conjunction with additional alterations of cell cycle control, a situation which is reminiscent of the development of human blastoid MCL.

p53 is a transcription factor that triggers growth inhibition and apoptosis [25]. p53 inactivation is the most common feature of human tumors. The frequent loss of p53 function in human lymphomas underscores its critical role in suppressing the emergence of incipient tumors [26]. A genetic anomaly initially restricted to c-myc deregulation clearly selects tumors with a homogeneous high proliferating signature and has no need for additional alteration of apoptotic pathways. Breeding of c-myc3'RR mice with p53-deficient mice confirmed the hypothesis that early alteration of apoptosis in a model of deregulated proliferation (i.e., 3'RR-driven c-myc overexpression in B-cells) induced tumor onset in a higher number of animals. Furthermore, these double mutant mice developed not only highly proliferative BL but also less proliferative types of lymphomas as observed in human patients where c-myc deregulation frequently occurs in pathologies such as MCL and plasmablastic cell lymphomas (PCL). While c-myc-3'RR mice developed non-activated $\mathrm{CD} 43^{-} \mathrm{BL}$, a wider pattern of lymphomas occurred in c-myc-3'RR/p53- mice including CD43- BL, $\mathrm{CD}_{4}{ }^{+} \mathrm{BL}$, MCL-like lymphoma $\left(\mathrm{IgM}^{+} \mathrm{CD}^{+} \mathrm{CD} 43^{+} \mathrm{CD} 23\right.$ cells) and PCL (IgM ${ }^{-/ l o w} \operatorname{IgD}^{-/ l o w} \mathrm{CD} 138^{+}$cells $)[27,28]$. This spectrum of tumors provided strong evidence that in the natural progression of lymphomagenesis, an initial defect in apoptosis can endow a 3'RR-mediated deregulation of c-myc to induce the occurrence of various types of mature B-cell lymphomas. This model thus accurately mimics the effect of c-myc translocation as seen in multiple human lymphomas.

Some B-cell lymphomas are associated with IgM or non IgM expression. B-cell receptor (BCR) signaling is essential for B-cell survival and response to antigens. BCR signaling varies not only among B-cell compartments but also among BCR classes. This suggests that different BCR signaling would affect lymphomagenesis. Breeding c-myc-3'RR mice in a genetic background ( $\alpha 1$-knock-in mice) [29] where IgA replaced IgM (IgA inducing stronger tonic BCR signaling than IgM) led to the generation of more differentiated $\mathrm{CD} 138^{+}$and less proliferative B-cell lymphomas [30]. BCR class-specific signals thus affect experimental c-myc-induced lymphomagenesis. The class of the BCR often correlates with the maturity of human B-cell tumors. IgM is thus associated with less differentiated malignancies $[31,32]$. IgA tumors in $\alpha 1-$ knock-in-c-myc-3'RR double mutant animals indicated that a class-switched BCR signal resulted in cell transformation with a more differentiated phenotype (and the occurrence of plasma cell lymphoma), then reminiscent of human plasma cell proliferations that overwhelmingly produce class-switched Ig. This could also be pertinent to observations made in patients, where $\operatorname{IgM}^{+}$malignancies are frequently more aggressive than related class-switched proliferations. Finally these results confirm the expression of the 3 'RR at the plasma cell stage.

The most convincing data for the essential 3'RR role in c-myc lymphomagenesis were brought by transgenic mice with IgH-c-myc translocations [33-37]. c-myc knock-in in the mouse IgH locus just 5' E $\mu$ (iMycE $\mu$ mice), modeling human endemic BL, induced B-cell lymphoma development after six months. Lymphomas in $\mathrm{iMycE} \mu$ mice had alterations in the p19 ${ }^{\text {Arf }}-\mathrm{Mdm} 2-\mathrm{p} 53$ tumor suppressor axis, a key pathway during c-mycinduced apoptosis [33]. Authors reported complex alterations with overexpressed $\mathrm{p} 19^{\text {Arf }}$ or lost $\mathrm{p} 19^{\text {Arf }}$ due to biallelic deletion of the Ink4a locus associated with overexpression of $\mathrm{Mdm} 2$ in some tumors and sometimes elevation of a presumably dysfunctional p53. NFkB/ STAT3/PI3K signaling crosstalk was later demonstrated to maintain c-myc-driven lymphomagenesis in iMycE $\mu$ mice [34]. The mouse plasmacytoma $\mathrm{T}(12 ; 15)$ translocation is a well-known cancer-associated chromosomal translocation in mice that join c-myc (in chromosome 15) with the IgH locus (in chromosome 12) [38]. iMycE $\mu$ mice also mimic the $\mathrm{T}(12 ; 15)$ translocation resulting in c-myc activation in murine plasmacytomas and thus also developed plasmacytomas [35]. In iMycE $\mu$ mice, c-myc is under transcriptional control of both the 3 ' $R R$ and $E \mu$. $\mathrm{E} \mu$ and 3'RR have activation kinetics clearly different with E $\mu$ acting in early B-cell development and the 3'RR in mature B-cell stages [2]. The definitive proof of an involvement of the 3'RR in B-cell lymphomagenesis was brought by iMycC $\mu$ mice carrying a c-myc knockin in the IgH locus just 5' of $\mathrm{C} \mu$ with deletion of $\mathrm{E} \mu$. The 3'RR alone (without E $\mu$ and/or putative E $\mu-3$ 'RR transcriptional crosstalk) is sufficient to deregulate c-myc expression in the B-cell lineage [36]. Plasmablastic neoplasms were rare in $\mathrm{iMycC} \mu$ but markedly increased after breeding with transgenic Kaposi Sarcoma-associated herpes-virus IL6 (vIL6) mice [36]. In this study authors validated their hypothesis that vIL6 mice may be a driver of transformation of B-cells to malignant cells. Finally knock-in insertion of c-myc directly into $\mathrm{C} \alpha$ just 5 ' to the 3'RR (iMycC $\alpha$ mice) produced infrequent plasma cell 
neoplasms (about 10\%) [37]. In contrast, after breeding with transgenic mice bearing the bcl- $\mathrm{X}_{\mathrm{L}}$ gene under the transcriptional Ig $\kappa$ light chain 3 ' enhancer, these double transgenic mice quickly developed plasma cell tumors. $\mathrm{Bcl}-\mathrm{X}_{\mathrm{L}}$ is a well-known anti-apoptotic molecule and the Ig $\kappa$ light chain 3' enhancer is of importance to drive Bcl$\mathrm{X}_{\mathrm{L}}$ expression specifically in the B-cell compartment from pre-B to mature B-cell stages. Taken altogether these knock-in models carrying c-myc at the IgH locus are prone to B-cell neoplasias of various penetrance, kinetics, and fate of knock-in bearing lymphocytes, highlighting the key role of IgH cis-regulatory enhancers (especially the 3'RR) for lymphoma progression. They also highlight the need for additional mutations in addition to c-myc deregulation to accelerate B-cell lymphoma development and that these "hits" target both proliferative, apoptotic and cytokine pathways.

\section{3'RR knock-out models of c-myc lymphomagenesis}

To elucidate 3'RR function, mice with genomic mutations were generated. Individual deletion (knockout mice) of hs3a [39], hs 1,2 [39], hs3b [40] or hs4 [41] has no effect on B-cell lymphopoiesis. In contrast deconstruction of the 3'RR palindrome structure [17] or deletion of two $[17,42]$, three [16] or four [8] of the 3'RR enhancers severely impaired B-cell lymphopoiesis. Mutant 3'RR mice were used in a few number of studies together with c-myc. 3'RR deleted mice showed that 3'RR was dispensable for the development of immature pro-Bcell lymphomas related to VDJ recombination-initiated c-myc translocations in double p53/Lig4 deficient mice [43]. 3'RR was not essential for the generation of IgHc-myc translocations in double p53/Xrcc4 deficient mice. However it had an important role in c-myc transcription after IgH-c-myc translocation thus leading to mature B-cell tumors [43]. These results are in agreement with the long distance effect of 3 ' $\mathrm{RR}$ on $\mathrm{IgH}$ transcription at mature B-cell stages. Transcriptional enhancers of $\kappa$ and $\lambda$ light chain loci efficiently deregulate c-myc. Mice carrying the c-myc gene under the transcriptional control of $\operatorname{Ig} \lambda$ enhancers (Ig $\lambda$-myc mice) developed BL [44]. Breeding Ig $\lambda$-myc mice in a 3 'RR-deficient background deviated B-cell lymphomagenesis toward less mature B-cell lymphomas most probably through a 3'RR action during B-cell development [45]. Indeed during B-cell development the 3 ' $R R$ is crucial for $\mu$ chain transcription and density of BCR expression at the B-cell membrane [11]. Together results from these 3'RR knock-out models indicate that deletion of 3 'RR markedly reduces the development of mature B-cell lymphomas highlighting the key role of this $\operatorname{IgH}$ cis-regulatory region for lymphoma progression.
Targeting the 3'RR: a promising therapeutic approach for c-myc induced B-cell lymphomas

The 3'RR is essential for high-rate Ig transcription $[8,11]$. Therefore, it may be a key stimulator of IgHtranslocated oncogene transcription. Breakpoints for oncogene translocations are sometimes several hundred $\mathrm{kb}$ away from the 3'RR. Data have reported that long-range interactions, through a loop structure, are implicated in both normal and abnormal regulation of 3'RR-induced gene transcription [46-48]. Of interest, physical interactions are also documented in resting and activated B-cells between E $\mu$ and 3'RR [46]. This structure facilitates switch-switch synapsis by approaching the switch $\mu$ region (proximal to $\mathrm{E} \mu$ ) and a downstream switch region (targeted by the 3'RR). Such loop structure is reported of importance for gene requiring a rapid transcriptional activation [46]. This suggests cooperative transcriptional effects between $\operatorname{IgH}$ cis-regulatory transcriptional enhancers that may explain why $\mathrm{E} \mu$ deletion between $\mathrm{iMycE} \mu$ mice and $\mathrm{iMycC} \mu$ mice has such an important effect on B-cell lymphoma development $[33,36]$. Therefore, as previously reported by us and others [4, 43], 3'RR targeting would in theory provide a potential strategy for the treatment of some mature B-cell lymphomas. Reinforcing this hypothesis, transgenic mice carrying $\mathrm{IgH}$ transgenes with the 3'RR (and independently of transgene chromosomal location, length, number and orientation) have been shown to undergo myc translocation into the transgene; these translocations generating plasmacytomas [49]. Thus the IgH constant region includes all elements necessary for both myc translocation and deregulation. Data also indicate that translocation/knock-in of c-myc to another chromosome changes its nuclear localization. In human BL cells the c-myc locus is relocalized from the nuclear periphery to the central, perinucleolar position [50]. In this setting, nucleolar proteins such as nucleolin (a polypeptide of 106 KDa constituting a part of the LR1 DNA binding protein which regulates transcription and switch recombination in mammalian B-cells) [51] may play a role in c-myc activation along with IgH cis-regulatory elements.

Translocations in B-cell lymphomas induce epigenetic changes [52]. This observation provides the opportunity to use new classes of anti-cancer agents, epigenetic drugs (EDs), that target histone acetylation (inhibitors of histone deacetylases, HDACi) and histone methylation (EZH2 inhibitors) to treat several B-cell lymphoid malignancies, such as MCL, FL, BL and others [53]. These drugs gave promising initial results in various clinical trials [54]. For example, preclinical data support the use of HDAC $i$ in combination with other antimyeloma agents [55, 56]. Surprisingly, the scientific basis to treat B-cell lymphomas with EZH2i and HDACi is not clear. How EDs act on B-cell lymphoma remain largely speculative. Is it via the role of the $3^{\prime} \mathrm{RR}$ on oncogene 
transcription? Data have documented that 3'RR activation and transcription can be down-regulated by several chemicals, including isothiocyanates (known to have anticarcinogenic properties) [57] and HDACi [58]. Studies have reported, in a model of $\mathrm{BL}$ translocations, that the 3'RR vastly remodelled large (up to $450 \mathrm{~kb}$ ) domains of translocated chromatin through epigenetic mark reprogramming [59]. We recently reported that 3'RRinduced effects are largely mediated through activation of specific epigenetic marks in a 3'RR targeted DNA [10] reinforcing that targeting the $\operatorname{IgH} 3$ 'RR would be of interest in the down-regulation of oncogene transcription. Moreover, 3'RR absence only weakly impacts chronic inflammatory ascites formation (penetrance, kinetic of development, cellular and pro-/ anti-inflammatory cytokine compositions) onto $\mathrm{BALB} / \mathrm{c}$ mice in response to pristine [60]. 3'RR-deficient B-cells remain efficient to develop oil granulomas in response to pristine with no differences for granuloma numbers, cellular composition and ability to express mRNA transcripts for several proand anti-inflammatory cytokines [61]. Altogether these results suggest a normal role for 3'RR-deficient B-cells in the development of an acute and chronic B-cell-mediated inflammatory response to pristine. These data reinforce the hypothesis which considers 3'RR as an interesting target for anti-lymphoma drug therapy with only low adverse effects on normal inflammatory and immune responses.

\section{CONCLUSIONS}

The 3'RR is of key importance for SHM, CSR and $\mu$ chain transcription. It follows that it is potentially of key importance as a deregulator for IgH-translocated oncogenes, even when breakpoints are hundreds of thousands bp away from the 3'RR. Long-range interactions through loop chromatin structures are common mechanisms of both normal and abnormal 3'RR-mediated gene transcription. Data have documented interactions between the 3'RR, E $\mu$ and the IgH locus in both normal B-cells and lymphomas. Mice transgenic for IgH-c-myc translocations have highlighted the important contribution of 3'RR in the development of mature B-cell lymphomas. Data obtained with these mice are transferable to human lymphomagenesis with respect to the high structural homology between mouse and human 3'RR. Thus, 3'RR targeted inhibition may be a potential therapeutic strategy for mature B-cell lymphoma treatments. Mouse models described herein may be useful tools for both in vitro and in vivo studies of 3'RR down-regulation treatments. Future studies will be necessary to clarify the rationale for treatment of B-cell lymphomas with HDACi and EZH2i: 1) by studying the biological functions and mechanisms of action of E $\mu$ and 3'RR and their cross-talk in the c-myc deregulation during experimental lymphomagenesis; 2) by identifying changes in the epigenome network occurring in lymphoma cells throughout the IgH locus; 3) by in vivo and in vitro testing of the role of various HDACi and EZH2i in the development of B-cell lymphomas; 4) by identifying genetic and epigenetic changes occurring in lymphoma cells upon acquisition of drug resistance during ED treatments; and 4) by identifying molecular mechanisms of these changes. Over the past decade convincing demonstrations of the 3 ' $R R$ contribution to mature c-myc-induced lymphomagenesis have been made using transgenic models. They may become now useful models for the study of treatment of B-cell lymphomas.

\section{ACKNOWLEDGMENTS}

This work was supported by grants from Conseil Régional du Limousin, Comité d'Orientation de la Recherche Cancérologie du Limousin (CORC:FJA/NP2015-109), Association pour la Recherche sur le Cancer (PJA 20141201649), Ligue Contre le Cancer (Comité de la Corrèze et Haute Vienne), Agence Nationale de la Recherche (ANR : projet EpiSwitch-3'RR 2016) and "Lions Club de la Corrèze, Zone 33 district 103 Sud". A. Saintamand was supported by a grant from fondation ARC (DOC20150602943). N. Ghazzaui was supported by a grant from Association de Spécialisation et d'Orientation Scientifique (Lebanon) and the municipality of Khiam (Lebanon).

\section{CONFLICTS OF INTEREST}

There are no conflicts of interest.

\section{REFERENCES}

1. Henderson A, Calame K. Transcription regulation during B cell development. Ann Rev Immunol. 1998; 16: 163-200.

2. Pinaud E, Marquet M, Fiancette R, Péron S, Vincent-Fabert C, Denizot Y, Cogné M. The IgH locus 3' regulatory region: pulling the strings from behind. Adv Immunol. 2011; 110: 27-70.

3. Sewastianik T, Prochorec-Sobieszek M, Chapuy B, Juszczynski P. MYC deregulation in lymphoid tumors: molecular mechanisms, clinical consequences and therapeutic implications. Biochim Biophys Acta. 2014; 1846: 457-467.

4. Saintamand A, Saad F, Denizot Y. 3'RR targeting in lymphomagenesis: a promising strategy? Cell Cycle. 2015; 14: 789-790.

5. Marquet M, Garot A, Bender S, Carrion C, Rouaud P, Lecardeur S, Denizot Y, Cogné M, Pinaud E. The E $\mu$ enhancer region influences $\mathrm{H}$ chain expression and $\mathrm{B}$ cell fate without impacting $\mathrm{IgVH}$ repertoire and immune response in vivo. J Immunol. 2014; 193: 1171-1183.

6. Rouaud P, Vincent-Fabert C, Saintamand A, Fiancette R, Marquet M, Robert I, Reina-San-Martin B, Pinaud E, Cogné M, Denizot Y. The IgH 3' regulatory region controls 
AID-induced somatic hypermutation in germinal centre B-cells in mice. J Exp Med. 2013; 210: 1501-1507.

7. Saintamand A, Vincent-Fabert C, Garot A, Rouaud P, Oruc Z, Magnone V, Cogné M, Denizot Y. Deciphering the importance of the palindromic architecture of the immunoglobulin heavy chain 3' regulatory region. Nature Commun. 2016; 7: 10730.

8. Vincent-Fabert C, Fiancette R, Pinaud E, Truffinet V, Cogné N, Cogné M, Denizot Y. Genomic deletion of the whole IgH 3' regulatory region (hs3a, hs1,2, hs3b, hs4) dramatically affects class switch recombination and Ig secretion to all isotypes. Blood. 2010; 116: 1895-1898.

9. Rouaud P, Saintamand A, Saad F, Carrion C, Lecardeur $\mathrm{S}$, Cogné M, Denizot Y. Elucidation of the enigmatic IgD class switch recombination via germ-line deletion of the IgH 3' regulatory region. J Exp Med. 2014; 211: 975-985.

10. Saintamand A, Rouaud P, Saad F, Rios G, Cogné M, Denizot Y. Elucidation of $\operatorname{IgH} 3$ ' region regulatory role during class switch recombination via germline deletion. Nature Commun. 2015; 6: 7084.

11. Saintamand A, Rouaud P, Garot A, Saad F, Carrion C, Oblet C, Cogné M, Pinaud E, Denizot Y. The IgH 3' regulatory region governs $\mu$ chain transcription in mature $\mathrm{B}$ lymphocytes and the B cell fate. Oncotarget. 2015; 6: 48454852. doi: 10.18632/oncotarget.3010.

12. Rouaud P, Vincent-Fabert C, Fiancette R, Cogné M, Pinaud E, Denizot Y. Enhancers located in heavy chain regulatory region (hs3a, hs1,2, hs3b and hs4) are dispensable for diversity of VDJ recombination. J Biol Chem. 2012; 287: 8356-8360.

13. D'addabbo P, Scascitelli M, Giambra V, Rocchi M, Frezza D. Position and sequence conservation in Amniota of polymorphic enhancer HS1,2 within the palindrome of IgH 3' regulatory region. BMC Evol Biol. 2011; 11: 71.

14. Chauveau C, Cogné M. Palindromic structure of the IgH 3' locus control region. Nature Genet. 1996; 14: 15-16.

15. Chauveau C, Decourt C, Cogné M. Insertion of the $\operatorname{IgH}$ locus 3' regulatory palindrome in expression vectors warrants sure and efficient expression in stable B cell transfectants. Gene. 1998; 222: 279-285.

16. Garot A, Marquet M, Saintamand A, Bender S, Le Noir S, Rouaud P, Carrion C, Oruc Z, Bébin AG, Moreau J, Lebrigand K, Denizot Y, Alt FW et al. Sequential activation and distinct functions for distal and proximal modules within the IgH 3'RR region. Proc Natl Acad Sci USA. 2016; 113: 1618-1623.

17. Saintamand A, Vincent-Fabert C, Garot A, Rouaud P, Oruc Z, Magnone V, Cogné M, Denizot Y. Deciphering the functional importance of the palindromic architecture of the immunoglobulin heavy chain 3' regulatory region. Nature Commun. 2016; 7: 10730.

18. Adams JM, Harris AW, Pinkert CA, Corcoran LM, Alexander WS, Cory S, Palmiter RD, Brinster RL. The c-myc oncogene driven by immunoglobulin enhancers induces lymphoid malignancy in transgenic mice. Nature. 1985; 318: 533-538.

19. Blum KA, Lozanski G, Byrd JC. Adult Burkitt leukemia and lymphoma. Blood. 2004; 104: 3009-3020.

20. Wang J, Boxer LM. Regulatory elements in the immunoglobulin heavy chain gene 3'-enhancers induce c-myc deregulation and lymphomagenesis in murine B cells. J Biol Chem. 2005; 280: 12766-12773.

21. Truffinet V, Pinaud E, Cogné N, Petit B, Guglielmi L, Cogné M, Denizot Y. The 3' IgH locus control region is sufficient to deregulate a c-myc transgene and promote mature B cell malignancies with a predominant Burkitt-like phenotype. J Immunol. 2007; 179: 6033-6042.

22. Vincent-Fabert C, Fiancette R, Truffinet V, Cogné N, Cogné M, Denizot Y. Genetic background modulates susceptibility to oncogen-driven proliferation and lymphoma occurrence in mice carrying a deregulated c-myc transgene. Leuk Res. 2009; 33: e203-e206.

23. Rane SG, Dubus P, Mettus RV, Galbreath EJ, Boden G, Reddy EP, Barbacid M. Loss of Cdk4 expression causes insulin-deficient diabetes and Cdk4 activation results in $\beta$-islet cell hyperplasia. Nature Genet. 1999; 22: 44-52.

24. Vincent-Fabert C, Fiancette R, Rouaud P, Baudet C, Truffinet V, Magnone V, Guillaudeau A, Cogné M, Dubus P, Denizot Y. A defect of the INK4-Cdk4 checkpoint and c-myc collaborate in blastoid mantle cell lymphoma (MCL)-like lymphoma formation in mice. Am J Pathol. 2012; 180: 1688-1701.

25. Yu J, Zhang L. The transcriptional targets of p53 in apoptosis control. Biochem Biophys Res Commun. 2005; 331: 851-858.

26. Martins CP, Brown-Swigart L, Evan GI. Modeling the therapeutic efficacy of p53 restoration in tumors. Cell. 2006; 127: 1323-1334.

27. Fiancette R, Rouaud P, Vincent-Fabert C, Laffleur B, Magnone V, Cogné M, Denizot Y. Y. A p53 defect sensitizes various stages of $\mathrm{B}$ cell development to lymphomagenesis in mice carrying an $\mathrm{IgH}$ 3' regulatory region-driven c-myc transgene. J Immunol. 2011; 187 : 5772-5782.

28. Rouaud P, Fiancette R, Vincent-Fabert C, Magnone V, Cogné M, Dubus P, Denizot Y. Mantle cell lymphoma-like lymphomas in c-myc-3'RR/p53+/- mice and c-myc-3'RR/ Cdk4R24C mice: differential oncogenic mechanisms but similar cellular origin. Oncotarget. 2012; 3: 586-593. doi: 10.18632/oncotarget.474.

29. Duchez S, Amin R, Cogné N, Delpy L, Sirac C, Pascal V, Corthésy B, Cogné M. Premature replacement of mu with alpha immunoglobulin chains impairs lymphopoiesis and mucosal homing but promotes plasma cell maturation. Proc Nat Acad Sci USA. 2010; 107: 3064-3069.

30. Amin R, Marfak A, Pangault C, Oblet C, Chanut A, Tarte $\mathrm{K}$, Denizot Y, Cogné M. The class-specific BCR tonic signal modulates lymphomagenesis in a c-myc deregulation 
transgenic model. Oncotarget. 2014; 15: 8995-9006. doi: 10.18632/oncotarget.2297.

31. Ruminy P, Etancelin P, Couronné L, Parmentier F, Rainville V, Mareschal S, Bohers E, Burgot C, Cornic M, Bertrand $\mathrm{P}$, Lenormand B, Picquenot JM, Jardin F et al. The isotype of the BCR as a surrogate for the GCB and $\mathrm{ABC}$ molecular subtypes in diffuse large B-cell lymphoma. Leukemia. 2011; 25: 681-688.

32. Avet-Loiseau H, Garand R, Lode L, Harousseau JL, Bataille R. Translocation $\mathrm{t}(11 ; 14)(\mathrm{q} 13 ; \mathrm{q} 32)$ is the hallmark of IgM, $\mathrm{IgE}$, and nonsecretory multiple myeloma variants. Blood. 2003; 101: 1570-1571.

33. Park SS, Kim JS, Tessarollo L, Owens JD, Peng L, Han SS, Tae Chung S, Torrey TA, Cheung WC, Polakiewicz RD, McNeil N, Ried T, Mushinski JF et al . Insertion of c-Myc into Igh induces B-cell and plasma-cell neoplasms in mice. Cancer Res. 2005; 65: 1306-1315.

34. Han SS, Yun H, Son DJ, Tompkins VS, Peng L, Chung ST, Kim JS, Park ES, Janz S. NF-kappaB/STAT3/PI3K signaling crosstalk in iMyc E mu B lymphoma. Mol Cancer. 2010; 9: 97.

35. Park SS, Shaffer AL, Kim JS, duBois W, Potter M, Staudt LM, Janz S. Insertion of Myc into Igh accelerates peritoneal plasmacytomas in mice. Cancer Res. 2005; 65: 7644-7652.

36. Rosean TR, Holman CJ, Tompkins VS, Jing X, Krasowski MD, Rose-John S, Janz S. KSHV-encoded vIL6 collaborates with deregulated c-MYC to drive plasmablastic neoplasm in mice. Blood Cancer J. 2016; 6: e398.

37. Cheung WC, Kim JS, Linden M, Peng L, Van Ness B, Polakiewicz RD, Janz S. Novel targeted deregulation of c-myc cooperates with Bcl-XL to cause plasma cell neoplasms in mice. J Clin Invest. 2004; 113: 1763-1773.

38. Janz S. Myc translocations in B cell and plasma cell neoplasms. DNA Repair. 2006; 5: 1213-1224.

39. Manis JP, van der Stoep N, Tian M, Ferrini R, Davidson L, Bottaro A, Alt FW. Class switching in B cells lacking 3' immunoglobulin. heavy chain enhancers. J Exp Med. 1998; 188: 1421-1431.

40. Bébin AG, Carrion C, Marquet M, Cogné N, Lecardeur S, Cogné M, Pinaud E. In vivo redundant function of the 3' $\mathrm{IgH}$ regulatory element $\mathrm{HS} 3 \mathrm{~b}$ in the mouse. J Immunol. 2010; 184: 3710-3717.

41. Vincent-Fabert C, Truffinet V, Fiancette R, Cogné N, Cogné M, Denizot Y. Ig synthesis and class switching do not require the presence of the hs4 enhancer in the 3' IgH regulatory region. J Immunol. 2009; 182: 6926-6932.

42. Pinaud E, Khamlichi AA, Le Morvan C, Drouet M, Nalesso V, Le Bert M, Cogné M. Localization of the 3' IgH locus elements that effect long-distance regulation of class switch recombination. Immunity. 2001; 15: 187-199.

43. Gostissa M, Yan CT, Bianco JM, Cogné M, Pinaud E, Alt FW. Long-range oncogenic activation of IgH-c-myc translocations by the $\operatorname{IgH} 3$ ' regulatory region. Nature. 2009; 462: 803-807.
44. Kovalchuk AL, Qi CF, Torrey TA, Taddesse-Heath L, Feigenbaum L, Park SS, Gerbitz A, Klobeck G, Hoertnagel K, Polack A, Bornkamm GW, Janz S, Morse HC 3rd. Burkitt lymphoma in the mouse. J Exp Med. 2000; 192: 1183-1190.

45. Saad F, Saintamand A, Cogné M, Denizot Y. The IgH 3' regulatory region influences lymphomagenesis in $\operatorname{Ig} \lambda$-Myc mice. Oncotarget. 2015; 6: 20302-20311. doi: 10.18632/ oncotarget.3963.

46. Wuerffel R, Wang L, Grigera F, Manis J, Selsing E, Perlot T, Alt FW, Cogne M, Pinaud E, Kenter AL. S-S synapsis during class switch recombination is promoted by distantly located transcriptional elements and activation-induced deaminase. Immunity. 2007; 27: 711-722.

47. Ju Z, Volpi SA, Hassan R, Martinez N, Giannini SL, Gold $\mathrm{T}$, Birshtein BK. Evidence for physical interaction between the immunoglobulin heavy chain variable region and the 3' regulatory region. J Biol Chem. 2007; 282: 35169-35178.

48. Xiang H, Noonan EJ, Wang J, Duan H, Ma L, Michie S, Boxer LM. The immunoglobulin heavy chain gene 3' enhancers induce Bcl2 deregulation and lymphomagenesis in murine B cells. Leukemia. 2011; 25: 1484-1493.

49. Spehalski E, Kovalchuk AL, Collins JT, Liang G, Dubois W, Morse HC 3rd, Ferguson DO, Casellas R, Dunnick WA. Oncogenic Myc translocations are independent of chromosomal location and orientation of the immunoglobulin heavy chain locus. Proc Natl Acad Sci USA. 2012; 109: 13728-13732.

50. Allinne J, Pichugin A, Iarovaia O, Klibi M, Barat A, ZlotekZlotkiewicz E, Markozashvili D, Petrova N, CamaraClayette V, Ioudinkova E, Wiels J, Razin SV, Ribrag V et al. Perinucleolar relocalization and nucleolin as crucial events in the transcriptional activation of key genes in mantle cell lymphoma. Blood. 2014; 123: 2044-2053.

51. Brys A, Maizels N. LR1 regulates c-myc transcription in B-cell lymphomas. Proc Natl Acad Sci USA. 1994; 91: 4915-4949.

52. Lindström MS, Wiman KG. Role of genetic and epigenetic changes in Burkitt lymphoma. Semin Cancer Biol. 2002; 12: 381-387.

53. Berg T, Thoene S, Yap D, Wee T, Schoeler N, Rosten P, Lim E, Bilenky M, Mungall AJ, Oellerich T, Lee S, Lai CK, Umlandt $\mathrm{P}$, et al. A transgenic mouse model demonstrating the oncogenic role of mutations in the polycomb-group gene EZH2 in lymphomagenesis. Blood. 2014; 123: 39143924.

54. Morschhauser F, Terriou L, Coiffier B, Bachy E, Varga A, Kloos I, Lelièvre H, Sarry AL, Depil S, Ribrag V. Phase 1 study of the oral histone deacetylase inhibitor abexinostat in patients with Hodgkin lymphoma, non-Hodgkin lymphoma, or chronic lymphocytic leukaemia. Invest. New drugs. 2015; 33: 423-431.

55. Kaufman JL, Fabre C, Lonial S, Richardson PG. Histone deacetylase inhibitors in multiple myeloma: rationale 
and evidence for their use in combination therapy. Clin Lymphoma Myeloma Leuk. 2013; 13: 370-376.

56. Richardson PG, Mitsiades CS, Laubach JP, Hajek R, Spicka I, Dimopoulos MA, Moreau P, Siegel DS, Jagannath S, Anderson KC. Preclinical data and early clinical experience supporting the use of histone deacetylase inhibitors in multiple myeloma. Leuk Res. 2013; 37: 829-837.

57. Henseler RA, Romer EJ, Sulentic CEW. Diverse chemicals including aryl hydrocarbon receptor ligands modulate transcriptional activity of the 3' immunoglobulin heavy chain regulatory region. Toxicology. 2009; 261: 9-18.

58. Lu ZP, Ju ZL, Shi GY, Zhang JW, Sun J. Histone deacetylase inhibitor trichostatin A reduces antiDNA autoantibody production and represses $\operatorname{IgH}$ gene transcription. Biochem Biophys Res Commun. 2005; 330: 204-209.
59. Kovalchuk AL, Ansarah-Sobrinho C, Hakim O, Resch W, Tolarová H, Dubois W, Yamane A, Takizawa M, Klein I, Hager GL, Morse HC 3rd, Potter M, Nussenzweig MC et al. Mouse model of endemic Burkitt translocations reveals the long-range boundaries of Ig-mediated oncogene deregulation. Proc Natl Acad Sci USA. 2012; 109: 1097210977.

60. Saad F, Saintamand A, Rouaud P, Denizot Y. Targeting the oncogene B lymphoma deregulator IgH 3' regulatory region does not impede the in vivo inflammatory response in mice. Oncoscience. 2014; 1: 591-598. doi: 10.18632/ oncoscience.81.

61. Ghazzaui N, Saintamand A, Issaoui H, Saad F, Denizot Y. Efficient role of IgH 3' regulatory region deficient B-cells in the development of oil granulomas. Oncotarget. 2016; 7: 38741-38749. doi: 10.18632/oncotarget.9588. 